\title{
Motivations to consume ecological foods in alternative food networks (AFNs) in Southern Spain
}

\author{
Sttefanie Yenitza Escobar-López and Angélica Espinoza-Ortega \\ Institute of Agricultural and Rural Sciences, \\ Autonomous Mexico State University, Toluca, Mexico \\ Carmen Lozano-Cabedo \\ National University of Distance Education, Madrid, Spain \\ Encarnación Aguilar-Criado \\ University of Sevilla, Sevilla, Spain, and \\ Santiago Amaya-Corchuelo \\ University of Cádiz, Cádiz, Spain
}

Motivations

to consume ecological foods in AFNs

Received 24 January 2019 Revised 11 June 2019 Accepted 19 July 2019

\begin{abstract}
Purpose - The purpose of this paper is to identify the motivations to consume ecological foods in alternative food networks (AFNs).

Design/methodology/approach - In total, 150 questionnaires were applied; the questionnaire was adapted from Food Choice Questionnaire (Steptoe et al., 1995). Data were analyzed by means of multivariate statistics with factor and cluster analysis. In order to identify statistical differences $(p<0.05)$, Kruskal-Wallis and Mann-Whitney nonparametric tests were performed.

Findings - Ten factors or motivations were found: social ecological concern, nutritional content, sensory aspects, certifications, naturalness, specialized consumption, trust in the seller, economic aspects, health and availability. Four groups were obtained and called: citizen consumers, in-process citizen consumers, conscious social consumers with no interest in certifications and conscious pragmatic consumers. It is concluded that differentiated consumers visit these establishments and their motivations are diverse, albeit they concur, to a varying extent, with the objectives of AFNs, finding a mixture of hedonic and ethical motivations.

Practical implications - This sort of works about specific places of consumption as well as specific consumers, in this case ecological, contributes to the development of future social research on other contexts, different consumers and products.

Originality/value - This sort of research has been carried out in various European cities, with a number of foods and over various sales channels; however, at present there is a debate around AFNs and the veracity of their goals. This way, the present work can contribute with an answer to whether the goals match the motivations of consumers.
\end{abstract}

Keywords Motives, Consumers, Ecological, Food Choice Questionnaire

Paper type Research paper

\section{Introduction}

During the 1970s and the 1980s, Europe witnessed expressions of social protest such as ecologist groups, fair trade, movements against globalization/global justice, among others, as a response to changes in food propitiated by contradictions in the global food system, the agricultural modernization by the so called Green Revolution and the exploiting relationships of the global supply chains (Goodman et al., 2012; Calo et al., 2012; Pérez Izquierdo et al., 2012; López García, 2011; Descals and Pérez, 2000).

As a consequence, various activist groups created new economic and social scenarios for the production, commerce and consumption of foods whose alternative, ethical and aesthetical qualities distinguish them from the conventionally-supplied foods, which additionally articulate the production and consumption of foods at hand, this way alternative food networks (AFNs) were born (Goodman et al., 2012; Lang, 2010).

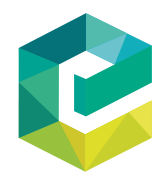

British Food Journal (C) Emerald Publishing Limited $0007-070 \mathrm{X}$ DOI 10.1108/BFJ-01-2019-0051 
Currently, these alternatives are still supported, for they are deemed prone to consolidate more sustainable food systems that favor the producer (Calo et al., 2012).

AFNs are spaces of quick integration into food economy, defined among other things by selling quality products from fair trade, local and ecological. In these networks, it is verified that both the production and consumption of foods are more closely related in a spatial, economic and social manner (Calo et al., 2012; Goodman et al., 2012; Veen et al., 2012; Goodman and Goodman, 2009). Among AFNs are find: local foods short supply chains; farmer markets; community agriculture; box systems; fair trade, among others (Simoncini, 2015; Tregear, 2011).

In such spaces, short commercialization channels (SCC) are strengthened and revalued (López García, 2011), the SCC represent a sort of connection between the city and the surrounding countryside and as an alliance between consumers and farmers; they mainly appear in metropolitan zones (Calo et al., 2012; López García, 2011). In recent years, supermarkets have demonstrated an interest as a response to the growing consumer demand (Maye and Kirwan, 2010).

The consumers of these sorts of products are increasingly critical and aware of the way the foods they acquire are produced (Olsen and Bánáti, 2014; Calo et al., 2012); they demand healthful food (Monteiro-Viana et al., 2014; Krom and Mol, 2010) natural, related to the producer and the local (Zanoli et al., 2012; Krom and Mol, 2010). These consumers are unique and distinguish themselves from the rest for they know how to identify what they want and demand higher quality (Zampila et al., 2015).

In this sense, the interest in ecological products has turned into a growing and irreversible tendency at a global scale (López García, 2011; Schwentesius Rinderman, 2010) because they are attractive as they come from a sort of agriculture that keeps soils, ecosystems and people healthy, based on ecological processes, biodiversity and cycles adapted to local conditions and combines tradition, innovation and science in order to benefit the shared environment and promote fair relationships and good quality of life for everyone involved (IFOAM, 2017; European Commission, 2017).

Nowadays, ecological agriculture is practiced in 179 countries, albeit it only accounts for 0.99 percent of the total global agricultural surface. Europe ranks second in the consumption of these products and it is the second continent that devotes the most surfaces to grow ecological foods after Oceania, being Denmark distinguishable as the first consumer (FiBL and IFOAM, 2017; Arriaga, 2014).

For its part, Spain is the main producer of ecological foods. It supplies 35 percent of what is consumed in the European continent; however, only 25 percent of its production is destined for domestic consumption, raking as the eighth European consumer; it is considered an occasional and marginal consumer, but on the increase (Arriaga, 2014; El sector ecológico en España, 2016; Fuentes and López de Coca, 2008). At internal level, Andalusia is catalogued as the leader in production and surface devoted to this activity, it comprises more than 50 percent of the total Spanish ecological surface and it is the leader in the consumption of these products (Bertuglia and Roa, 2017; Junta de Andalucía, 2016).

The increasing consumption of ecological foods has become a topic of interest for research from various standpoints, in this regard De Maya et al. (2011) and Zander and Hamm (2010) comment that there is an area of opportunity in ascertaining the perception and motives for consumption. Thus, several works have identified that motivations are heterogeneous and they divide into two tendencies. The first is the hedonic or egotistic consumption, which brings pleasure and joy merely by the fact of purchasing the foods (Bakırtaş and Uslu, 2013; Alba and Williams, 2013) and is boosted by the search for benefits for individual health, innocuousness, quality, flavor, freshness, authenticity, naturalness and nutritional content (Lee and Yun, 2015; Vega-Zamora et al., 2013; Van Loo et al., 2014; Zanoli et al., 2012; Krom and Mol, 2010; Zander and Hamm, 2010). 
The second is the ethical or altruistic consumption, in which the consumer considers the effect their purchase decision has on public well-being and the world around them (Langen, 2012); an example of this is concern for animal welfare, environmental protection, rural and local development and taking care for agriculture (Lee and Yun, 2015; Vega-Zamora et al., 2013; Van Loo et al., 2014; Zanoli et al., 2012; Krom and Mol, 2010; Zander and Hamm, 2010).

Before the role of Spain as a country that produces ecological foods in Europe and being Andalusia a leader in consumption, the present work has as an aim to identify the motivations to consume these foods in AFNs.

\section{Methodology}

Data were collected via the application of questionnaires in ecological markets in Seville. The study was applied at random (Keith et al., 2002) to consumers over 18 years of age (Rojas-Rivas et al., 2018; De Maya et al., 2011; Díaz Víquez et al., 2015). For the total number of questionnaires to apply, we followed the recommendations by Field (2013) and Hair et al. (1999) for cluster analyses, which require five cases per analyzed variable, this is to say, a total of 150 questionnaires were applied.

The questionnaire was an adaptation of Food Choice Questionnaire (FCQ) (Steptoe et al., 1995) and other variables from previous studies (Escobar-López et al., 2017; Lee and Yun, 2015; Vega-Zamora et al., 2013; Zander and Hamm, 2010). It consists of three sections. The first refers to how often they consume these foods and if they are aware of the information about them. The second deals with the reasons for their selection (FCQ) (Lee and Yun, 2015; Vega-Zamora et al., 2013; Zander and Hamm, 2010; Steptoe et al., 1995); answers were measured using a five-point Likert scale, where $1=$ not important and $5=$ very important (Lee and Yun, 2015; Mohamad et al., 2014; Vega-Zamora et al., 2013; Aschemann-Witzel et al., 2013). The third section comprises socioeconomic data on sex, age, marital status, schooling and occupation (Fotopoulos et al., 2009).

The data obtained from the sections on information and frequency, and socioeconomic profile were analyzed with descriptive statistics, whereas regarding the section on motivation, using software SPSS for multivariate factor analysis (Aschemann-Witzel et al., 2013; Zander and Hamm, 2010), by means of which was identified relations between items and reasons for selection, where we resorted to Kaiser-Meyer-Olkin (KMO) test as a measure of suitability and adequacy of the sample, having $p>0.05$ as an acceptable value for factor analysis (Field, 2013).

With the factorial loads obtained (Field, 2013), cluster analysis was run (Martín et al., 2008; Pedroza and Discovsky, 2006; Álvarez, 1995) in order to identify groups of consumers according to their common characteristics (De Maya et al., 2011; Field, 2013; Fotopoulos et al., 2009; Steptoe et al., 1995). Finally, the nonparametric KrusKal-Wallis and MannWhitney tests were applied to find statistical differences $(p<0.05)$ between groups in relation to the factors obtained (Field, 2013; Hair et al., 1999).

\section{Results}

\subsection{Factor analysis}

The analysis identified ten factors with 66.33 percent of accumulated variance and KMO of 0.690. The factors were called according to the positive and negative associations presented by the analyzed items, being as follows: social ecological concern; nutritional content; sensory aspects; certifications; naturalness; specialized consumption; trust in the seller; economic aspects; health and; availability (Table I).

\subsection{Characteristics of the identified groups}

In cluster analysis, four groups were identified and named after their characteristics such as citizen consumers; in-process citizen consumers; conscious social consumers with no interest in certifications; and conscious pragmatic consumers (Figure 1).
Motivations

to consume ecological

foods in AFNs 
$\mathrm{BFJ}$

\begin{tabular}{|c|c|c|c|}
\hline Factor name & Item & $\begin{array}{c}\% \\
\text { Variance } \\
\end{array}$ & $\begin{array}{l}\% \text { Accumulated } \\
\text { variance } \\
\end{array}$ \\
\hline $\begin{array}{l}\text { 1. Social } \\
\text { ecological } \\
\text { concern }\end{array}$ & $\begin{array}{l}\text { I eat them because they do not affect the balance of nature } \\
\text { I eat them because I help build a better world } \\
\text { Their consumption improves my health } \\
\text { I choose ecological foods because they are produced locally } \\
\text { I eat them because when they are packed it is done with } \\
\text { respect for the environment } \\
\text { Consuming them decreases pollution } \\
\text { I eat them because they do not pollute water with chemicals } \\
\text { When I eat them I feel I am doing the right thing }\end{array}$ & 18.27 & 18.27 \\
\hline $\begin{array}{l}\text { 2. Nutritional } \\
\text { content }\end{array}$ & $\begin{array}{l}\text { I eat them because of their content of vitamins and minerals } \\
\text { I eat them because of their nutritional content } \\
\text { Their nutritional intake is important to me }\end{array}$ & 9.13 & 27.4 \\
\hline $\begin{array}{l}\text { 3. Sensory } \\
\text { aspects }\end{array}$ & $\begin{array}{l}\text { I eat them because they look nice } \\
\text { I prefer them because of their smell } \\
\text { I choose them because of their flavor }\end{array}$ & 7.46 & 34.86 \\
\hline 4. Certifications & $\begin{array}{l}\text { I verify they bear the ecological seal } \\
\text { I check the information on the tag }\end{array}$ & 6.32 & 41.18 \\
\hline 5. Naturalness & $\begin{array}{l}\text { I eat them because they are chemical-free } \\
\text { I eat them because of their natural ingredients } \\
\text { I eat them because they are free from artificial ingredients }\end{array}$ & 5.24 & 46.42 \\
\hline $\begin{array}{l}\text { 6. Specialized } \\
\text { consumption }\end{array}$ & $\begin{array}{l}\text { I travel far to buy them } \\
\text { I look for them in specialized places }\end{array}$ & 4.55 & 50.97 \\
\hline $\begin{array}{l}\text { 7. Trust in the } \\
\text { seller }\end{array}$ & $\begin{array}{l}\text { I always acquire ecological foods from the same seller } \\
\text { I trust in what the seller tells me } \\
\text { I eat them because their price is fair }\end{array}$ & 4.27 & 55.24 \\
\hline $\begin{array}{l}\text { 8. Economic } \\
\text { aspects }\end{array}$ & $\begin{array}{l}\text { I acquire them regardless of their price }(-) \\
\text { A high price does not decide on my consumption frequency } \\
\text { The origin of ecological foods restricts my consumption }\end{array}$ & 3.91 & 59.15 \\
\hline 9. Health & $\begin{array}{l}\text { I eat them to prevent diseases } \\
\text { When I eat them I think of cancer }\end{array}$ & 3.65 & 62.8 \\
\hline $\begin{array}{l}\text { 10. Availability } \\
\text { Note: (-) Negati }\end{array}$ & $\begin{array}{l}\text { I would like to find them easily } \\
\text { association }\end{array}$ & 3.53 & 66.33 \\
\hline
\end{tabular}

Figure 1.

Characteristics of the groups according to the factors identified
Obtained factors and their corresponding variables 
Table II shows the statistical differences $(p<0.001)$ by group for the obtained factors. The first group displays statistically significant differences $(p<0.001)$ in factors ecological concern, nutritional content, sensory aspects, certifications, naturalness and economic aspects.

Regarding the second group called "In-process citizen consumers"; it displayed statistically significant differences $(p<0.001)$ in factors nutritional content, certifications and naturalness in comparison with the other three groups. The third group called "Conscious social consumers with no interest in certifications" did not present statistically significant differences $(p<0.001)$, coinciding in each factor with any of the other three groups. Finally, the group called "Conscious pragmatic consumers" showed statistically significant differences $(p<0.001)$ in factors ecological concern, naturalness and specialized consumption.

The group "Citizen consumers" accounted for 38 percent of the respondents, it was called this way as it obtained the highest scores for the ten factors, evincing the concern about the way to produce the foods does not pollute the environment and that they are free from chemicals, nutritious and easily available, among other relevant factors such as trust in the seller, this is to say, not only do consumers look for their own benefit, but also for their environment.

The group called "In-process citizen consumers" accounted for 33 percent of the respondents. This group concurs with the previous on motives such as availability, health and specialized consumption, being the latter one of the least relevant, together with sensory aspects, economic aspects and trust in the seller. The most important reasons for this group are naturalness, availability, ecological concern, certifications and nutritional content and health. This shows consumers undergoing a change in order to give more importance to reasons for consumption.

The group "Conscious social consumers with no interest in certifications" accounted for 20 percent of the respondents; it was called so because for them the variables naturalness, availability, ecological concern, trust and nutritional content are important. They are consumers interested in eating foods free from chemicals, amiable with the environment and geographically close; albeit, aspects such as specialized consumption, economic aspects, sensory aspects, certifications and health are not relevant for them, which shows a noticeable difference in the importance they give to certifications regarding the two previous groups, this is to say, the world around them is important for them, not a seal that guarantees the food they eat.

Finally, the group "Conscious pragmatic consumers" accounted for only 9 percent of the respondents. It is different from the three previous groups in social ecological concern,

\begin{tabular}{|c|c|c|c|c|c|c|c|c|c|}
\hline \multirow[b]{2}{*}{ Factor name } & \multicolumn{2}{|c|}{$\begin{array}{l}\text { Citizens } \\
(n=57)\end{array}$} & \multicolumn{2}{|c|}{$\begin{array}{c}\text { In-process } \\
\text { citizens } \\
(n=49)\end{array}$} & \multicolumn{2}{|c|}{$\begin{array}{c}\text { Conscious social } \\
\text { consumers with no } \\
\text { interest in } \\
\text { certifications }(n=31)\end{array}$} & \multicolumn{2}{|c|}{$\begin{array}{c}\text { Conscious } \\
\text { pragmatic } \\
\text { consumers } \\
(n=13)\end{array}$} & \multirow[b]{2}{*}{$p^{2}$} \\
\hline & Median & $\mathrm{IQR}$ & Median & $\mathrm{IQR}$ & Median & $\mathrm{IQR}$ & Median & $\mathrm{IQR}$ & \\
\hline 1. Ecological concern & $5.0^{\mathrm{a}}$ & 0.7 & $4.7^{\mathrm{b}}$ & 1.7 & $4.7^{\mathrm{b}}$ & 1.2 & $4.0^{\mathrm{c}}$ & 3.4 & 0.001 \\
\hline 2. Nutritional content & $5.0^{\mathrm{a}}$ & 1.0 & $4.3^{\mathrm{b}}$ & 3.0 & $3.7^{\mathrm{c}}$ & 4.0 & $3.7^{\mathrm{c}}$ & 4.0 & 0.001 \\
\hline 3. Sensory aspects & $4.3^{\mathrm{a}}$ & 2.0 & $3.0^{\mathrm{b}}$ & 4.0 & $3.0^{\mathrm{b}}$ & 4.0 & $3.7^{\mathrm{b}}$ & 3.3 & 0.001 \\
\hline 4. Certifications & $4.0^{\mathrm{a}}$ & 4.0 & $4.5^{\mathrm{b}}$ & 4.0 & $2.0^{\mathrm{c}}$ & 4.0 & $2.0^{c}$ & 4.0 & 0.001 \\
\hline 5. Naturalness & $5.0^{\mathrm{a}}$ & 0.3 & $5.0^{\mathrm{b}}$ & 0.7 & $5.0^{c}$ & 1.0 & $4.3^{\mathrm{d}}$ & 1.0 & 0.001 \\
\hline 6. Specialized consumption & $3.5^{\mathrm{a}}$ & 4.0 & $3.0^{\mathrm{a}}$ & 3.5 & $3.5^{\mathrm{a}}$ & 4.0 & $2.0^{\mathrm{b}}$ & 2.5 & 0.002 \\
\hline 7. Trust in the seller & $4.0^{\mathrm{a}}$ & 3.0 & $3.5^{\mathrm{bc}}$ & 4.0 & $4.0^{\mathrm{ab}}$ & 3.5 & $4.0^{c}$ & 4.0 & 0.003 \\
\hline 8. Economic aspects & $3.7^{\mathrm{a}}$ & 3.3 & $3.3^{\mathrm{b}}$ & 3.0 & $3.3^{\mathrm{bc}}$ & 2.7 & $2.7^{\mathrm{c}}$ & 2.3 & 0.001 \\
\hline 9. Health & $4.0^{\mathrm{a}}$ & 3.0 & $4.0^{\mathrm{a}}$ & 3.5 & $2.0^{\mathrm{b}}$ & 4.0 & $3.0^{\mathrm{b}}$ & 4.0 & 0.001 \\
\hline 10. Availability & $5.0^{\mathrm{a}}$ & 2.0 & $5.0^{\mathrm{a}}$ & 2.0 & $5.0^{\mathrm{b}}$ & 4.0 & $5.0^{\mathrm{ab}}$ & 1.0 & 0.013 \\
\hline
\end{tabular}

Notes: $\mathrm{IQR}=$ interquartile range; $p^{2}=$ value of the Kruskal-Wallis test $(p<0.05) ; \mathrm{a}, \mathrm{b}, \mathrm{c}, \mathrm{d}=\mathrm{Mann}-$ Whitney $U$-test $(p<0.05){ }^{\mathrm{a}, \mathrm{b}, \mathrm{c}, \mathrm{d}}$ Different letters by row are different

Motivations

to consume ecological foods in AFNs

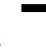


naturalness and specialized consumption. They are consumers who disregard about their own health, the price of products and whether they have seals; nevertheless, they consider relevant that these products are respectful with the environment (Table III).

In connection with socioeconomic aspects, the three first groups comprise more than 50 percent of women, unlike the fourth that holds 69 percent of men. The four groups presented similar characteristics in relation to age, marital status, education and occupation. They can be considered young adults as more than 45 percent is aged from 36 to 55 years; more than 40 percent is married, it is important to underscore for this aspect that the group "Conscious pragmatic consumers" was the one with the highest percentage (92 percent); moreover, they are notable for having a high educational level, more than 70 percent holds a degree or postgraduate studies and more than 40 percent is an employee.

\section{Discussion}

The number of factors obtained in the present work was superior in comparison with other works that report from five to nine factors (Bertuglia and Roa, 2017; Escobar-López et al., 2017; Lee and Yun, 2015; Mohamad et al., 2014; Sevilla Guzmán et al., 2012; Stolz et al., 2011);

on the other side, it agrees with the factors obtained by Zander and Hamm (2010).

\begin{tabular}{|c|c|c|c|c|}
\hline Variable & $\begin{array}{l}\text { Citizen } \\
(n=57) \\
\end{array}$ & $\begin{array}{l}\text { Citizen with emphasis on } \\
\text { environmental aspects }(n=49)\end{array}$ & $\begin{array}{l}\text { Socially conscious without } \\
\text { interests in certifications }(n=31)\end{array}$ & $\begin{array}{c}\text { Pragmatically } \\
\text { conscious } \\
(n=13)\end{array}$ \\
\hline \multicolumn{5}{|l|}{ Sex $\%$} \\
\hline Woman & 72 & 76 & 55 & 31 \\
\hline Man & 28 & 24 & 45 & 69 \\
\hline \multicolumn{5}{|l|}{ Age \% } \\
\hline $18-35$ & 30 & 20 & 23 & 23 \\
\hline $36-55$ & 61 & 49 & 61 & 62 \\
\hline 56-75 & 9 & 31 & 13 & 15 \\
\hline $76+$ & 0 & 0 & 3 & 0 \\
\hline \multicolumn{5}{|c|}{ Marital status \% } \\
\hline Single & 31 & 33 & 39 & 8 \\
\hline Married & 58 & 57 & 48 & 92 \\
\hline Other & 11 & 10 & 13 & 0 \\
\hline \multicolumn{5}{|l|}{ Education \% } \\
\hline $\begin{array}{l}\text { Elementary/ } \\
\text { secondary }\end{array}$ & 9 & 4 & 7 & 0 \\
\hline High school/ & & & & \\
\hline technician & 21 & 18 & 19 & 0 \\
\hline $\begin{array}{l}\text { Graduate/ } \\
\text { postgraduate }\end{array}$ & 70 & 78 & 74 & 100 \\
\hline No studies & 0 & 0 & 0 & 0 \\
\hline \multicolumn{5}{|l|}{ Occupation \% } \\
\hline Student & 7 & 12 & 0 & 0 \\
\hline Employee & 44 & 47 & 68 & 54 \\
\hline Worker & 2 & 0 & 0 & 0 \\
\hline \multicolumn{5}{|l|}{ Independent } \\
\hline Retiree & 3 & 6 & 0 & 7 \\
\hline Homemaker & 10 & 12 & 10 & 0 \\
\hline Unemployed & 13 & 6 & 0 & 8 \\
\hline
\end{tabular}

Table III.

Comparative analysis of the socioeconomic variables by group 
The most important factor was social ecological concern, concurring with Escobar-López et al. (2017) and Basha et al. (2015); although it is mentioned as a determinant in other works, it is not the most important aspect to mediate the choice of ecological foods (Basha et al., 2015; Lee and Yun, 2015; Van Loo et al., 2014; Hjelmar, 2011). With reference to nutritional content authors such as Lee and Yun (2015) mention it as the main factor to opt for these products; in the present study, it holds the second place.

This way, awareness of the noxious effects of the production of conventional foods is increasing among the consumers, who have expressed their concerns about the growing levels of use of chemical fertilizers (Basha et al., 2015; Zanoli et al., 2012; Pinstrup-Andersen, 2011; Krom and Mol, 2010). As a response, there appears a consumer who deems ecological foods environmentally friendly, since pesticides, fertilizers, hormones or antibiotics are not necessary to produce them (Escobar-López et al., 2017; Al-Taie et al., 2015; Basha et al., 2015; Lee and Yun, 2015; Van Loo et al., 2014; Hjelmar, 2011), which is evinced by the obtained results.

In a study carried out by Sevilla Guzmán et al. (2012) on the short food commercialization channels in Andalusia, the most mentioned reasons to consume ecological foods are longing, learning about agriculture, quality products, diffusion of ecological farming, participation and affinity, economic and environmental aspects, healthy eating and social change. The results of the present work concur with the last four factors above; however, not in the same order of appearance.

Furthermore, in their work on the reasons that determine whether consuming or not consuming ecological foods in the Metropolitan Area of Granada, Spain and the preferences of the consumer regarding them, Bertuglia and Roa (2017) obtained nine factors and as for the preferences of consumers they found that flavor was the most important, followed by nutritional value, geographic origin, quality label, price, sort of package, durability, brand and lastly, easy preparation. For the present work, these factors were among the ones we obtained, only the last was not mentioned.

This way, it is noticed that the obtained factors are present in studies undertaken in other countries, on occasion they match, on others not in the same order of importance or under another name (Lee and Yun, 2015; Lim et al., 2014; Hjelmar, 2011). In this respect, Escobar-López et al. (2017) mention that there is no rule or regularity in the number of motivations to choose foods, as each population is distinct; the same occurs in the degree of importance they give each motivation.

Moreover, in this study we found four sorts of consumers, being the same as the number Escobar-López et al. (2017) reported; they identified conscious consumers interested in certifications, which matches with citizen consumers; conscious consumers with no interest in certifications, this group has a similar behavior to in-process citizen consumers, as they are learning to give more importance to reasons for consumption, at the same time, they share the little interest in certifications with the former: opportunistic consumers in transition and unconsciously opportunistic consumers. Authors such as Tsourgiannis et al. (2015), Wu et al. (2014) and Chen et al. (2014) only identified three groups, naming them after their characteristics.

Gómez-Benito and Lozano (2014) mention that a "citizen consumer" is the individual capable of fulfilling their personal desires and promoting collective responsibility and common good at once, this is to say, such power based on purchase decision offers an opportunity to exercise their right to citizenship. In this sense, both the groups citizen consumers and in-process citizen consumers of the present work match such definition as they exhibit individual as well as collective motivations. For their part, Tavernier (2011) categorizes these consumers as main actors, concurring once more with our results.

As regards socioeconomic characteristics, our results agree with a number of works, where more than 50 percent of the samples comprised women, young adults, married and with high educational level, graduate and postgraduate studies (Escobar-López et al., 2017;
Motivations

to consume ecological

foods in AFNs 

2014; Mohamad et al., 2014; Van Loo et al., 2014; Wu et al., 2014; Sevilla Guzmán et al., 2012).

Authors such as Al-Taie et al. (2015) reported that youths and young adults are increasingly aware of the benefits that ecological foods can produce on health and the environment; for their part, Petrescu and Petrescu-Mag (2015) mentioned that the age group that holds these beliefs tightly is that from 36 to 45 years. Olsen and Bánáti (2014) and Kriwy and Mecking (2012) found out that as educational level increases, so does willingness to incorporate new foods into the diet; in this sense, Teng and Wang (2015) concluded that if consumers perceive and understand well ecological farming, trust is more like to build up, which in turn positively influences their attitudes toward foods.

Taking into account the above, i.e., the multiple factors or reasons to decide on eating ecological foods and the various consumer groups we obtained, as well as the place where the present work was developed, it is relevant to mention that authors such as EscobarLópez et al. (2017), who identified the reasons to consume these foods in outdoor and ecological markets, mention that the place where purchases are made may influence the reasons for consumption.

In this sense, AFNs are seen as spaces where integral practices are performed in connection with food provision (Barbera and Dagnes, 2016), which favor the producer (Calo et al., 2012), develop economic, spatial and social links between production and consumption (DesRivières et al., 2017; Calo et al., 2012; Goodman et al., 2012; Veen et al., 2012; Goodman and Goodman, 2009) and strengthen SCC (López García, 2011).

In view of the foregoing, they turn into attractive spaces for the consumption of local quality foods, ecological and from fair trade (Cerrada-Serra et al., 2018; Calo et al., 2012; Goodman et al., 2012; Veen et al., 2012; Goodman and Goodman, 2009), attracting attention from certain groups of consumers who have other sorts of demands (Gómez Cruz et al., 2003). In this work, we found four groups with specific general characteristics and distinct reasons that differentiate them from conventional consumers.

Furthermore, according to Feenstra (1997), AFNs are particular places where there are interchanges that go beyond the economic; a sort of consumption that moves away from the individualistic takes place (Click and Ridberg, 2010), as the results evince, motivations such as social ecological concern and trust in the seller are present; thus the buyers become consumers concerned about the environment and the actors engaged in this activity.

Adding to that, AFNs are a phenomenon more closely related to the urban than the rural, it seems as though consumers from the city and its surroundings are more interested in looking for alternative food chains (Barbera and Dagnes, 2016). Grunert et al. (2011) refer that social and economic transformations produce significant changes in food purchasing patterns in urban households; an aspect found in the spaces where the present work was developed.

\section{Conclusions}

Even if the four groups obtained have the same reasons to buy ecological foods, they display a differentiated behavior by giving each of them various degrees of importance. By and large, it is noticed that the first motivation is social ecological concern, this is to say, consumers are interested in the local impacts on nature and the world around them, which is ensued by hedonic motivations (consumers looking for their self-benefit). Indubitably, these are differentiated consumers, interested in quality local foods that benefit the world around them; however, there is a mixture of hedonic and ethical motives, being the former the most stressed.

This way, it can be said that AFNs are promising spaces, as they attract various sorts of consumers with different motivations, but which concur with the goals stated at their inception. Albeit, producers are important in the perception, there is still work to do to turn them into one of the main motivations. 
Identifying the motivations present in the consumption of ecological foods in these sorts of spaces, as it is noticed in the present work, poses challenges, offers opportunities and has the potential to unfold better strategies that benefit every actor involved in the process of production, commercialization and consumption of these products.

Motivations

to consume ecological

foods in AFNs

\section{References}

Alba, W. and Williams, F. (2013), "Pleasures principles: a review of research on hedonic consumption", Journal of Consumer Psychology, Vol. 23 No. 1, pp. 2-18.

Al-Taie, W.A., Rahal, M.K., AL-Sudani, A.S. and AL-Farsi, K.A. (2015), "Exploring the consumption of organic foods in the United Arab Emirates", Sage Open, Vol. 5 No. 2, pp. 1-12.

Álvarez, C. (1995), "Estadística multivariante y no paramétrica con SPSS", Aplicación a las ciencias de la salud, Ediciones Díaz de Santos, Madrid.

Arriaga, E. (2014), Estudio de los Hábitos de Consumo de productos Ecológicos de los Habitantes de Tierra Estrella, España, Universidad Pública de Navarra.

Aschemann-Witzel, J., Maroscheck, N. and Hamm, U. (2013), "Are organic consumers preferring or avoiding foods with nutrition and health claims?”, Food Quality and Preference, Vol. 30 No. 1, pp. 68-76.

Bakırtaş, H. and Uslu, D. (2013), "The effect of hedonic shopping motivation on consumer satisfaction and consumer loyalty”, International Journal of Asian Social Science, Vol. 3 No. 7, pp. 2226-5139.

Barbera, F. and Dagnes, J. (2016), "Building alternatives from the bottom-up: the case of alternative food networks", Agriculture and Agricultural Science Procedia, Vol. 8, pp. 324-331.

Basha, M.B., Mason, C., Shamsudin, M.F., Hussain, H.I. and Salem, M.A. (2015), "Consumers attitude towards organic food", Procedia Economics and Finance, Vol. 31, pp. 444-452.

Bertuglia, A. and Roa, M.C.G. (2017), "Actitud del consumidor frente a los productos ecológicos: resultados de un estudio en el área metropolitana de Granada”, Distribución y Consumo, Vol. 27 No. 149 , pp. 116-122.

Çabuk, S., Tanrikulu, C. and Gelibolu, L. (2014), "Understanding organic food consumption: attitude as a mediator", International Journal of Consumer Studies, Vol. 38 No. 4, pp. 337-345.

Calo, I.G., Giménez, T.D.H., Real, E.R. and Renting, H. (2012), "Circuitos cortos de comercialización en Andalucía: un análisis exploratorio”, Revista Española de Estudios Agrosociales y Pesqueros, No. 232, pp. 193-227.

Cerrada-Serra, P., Moragues-Faus, A., Zwart, T.A., Adlerova, B., Ortiz-Miranda, D. and Avermaete, T. (2018), "Exploring the contribution of alternative food networks to food security: a comparative analysis", Food Security, Vol. 10 No. 6, pp. 1371-1388.

Chen, J., Lobo, A. and Rajendran, N. (2014), "Drivers of organic food purchase intentions in mainland China - evaluating potential customers' attitudes, demographics and segmentation”, International Journal of Consumer Studies, Vol. 38 No. 4, pp. 346-356.

Click, M.A. and Ridberg, R. (2010), "Saving food: food preservation as alternative food activism", Environmental Communication, Vol. 4 No. 3, pp. 301-317.

De Maya, S.R., López- López, I. and Munuera, J.L. (2011), "Organic food consumption in Europe: International segmentation based on value system differences", Ecological Economics, Vol. 70 No. 10 , pp. 1767-1775.

Descals, A.M. and Pérez, M.S. (2000), "Análisis de los cambios en los canales de comercialización, de productos agroalimentarios", Revista Española de Estudios Agrosociales y Pesqueros, No. 186, pp. 39-74.

DesRivières, C.P., Chuenpagdee, R. and Mather, C. (2017), "Reconnecting people, place, and nature: examining alternative food networks in New foundland's fisheries", Agriculture \& Food Security, Vol. 6 No. 1. 
Díaz Víquez, A., Pérez Hernández, A. and Hernández Ávila, J. (2015), "Caracterización del consumidor de productos orgánicos en la ciudad de Toluca”, Revista Mexicana de Agronegocios, Vol. 19 No. 36 , pp. 1178-1187.

El sector ecológico en España (2016), "El sector ecológico en España”, available at: http://pae.gencat. cat/web/.content/al_alimentacio/al01_pae/05_publicacions_material_referencia/arxius/2016_ Informe_EcoLogical.pdf (accessed June 2017).

Escobar-López, S.Y., Espinoza-Ortega, A., Vizcarra-Bordi, I. and Thomé-Ortíz, H. (2017), "The consumer of food products in organic markets of central Mexico", British Food Journal, Vol. 119 No. 3, pp. 558-574.

European Commission (2017), "Organics at a glance", available at: https://ec.europa.eu/info/foodfarming-fisheries/farming/organic-farming/organics-glance (accessed November 2017).

Feenstra, G.W. (1997), "Local food systems and sustainable communities", American Journal of Alternative Agriculture, Vol. 12 No. 1, pp. 28-36.

FiBL and IFOAM (2017), "The world of organic agriculture 2017", The Research Institute of Organic Agriculture, International Federation of Organic Agriculture Movements, available at: www. organic-world.net/yearbook/yearbook-2017/pdf.html (accessed October 10, 2017).

Field, A. (2013), Discovering Statistics Using IBM SPSS Statistics, SAGE Publications, London.

Fotopoulos, C., Krystallis, A., Vassallo, M. and Pagiaslis, A. (2009), "Food Choice Questionnaire (FCQ) revisited: suggestions for the development of an enhanced general food motivation model", Appetite, Vol. 52 No. 1, pp. 199-208.

Fuentes, C. and López de Coca, E. (2008), "El Consumo de productos ecológicos", Distribución y Consumo, No. 99, pp. 5-24.

Gómez-Benito, C. and Lozano, C. (2014), "Constructing food citizenship: theoretical premises and social practices”, Italian Sociological Review, Vol. 4 No. 2, pp. 135-156.

Gómez Cruz, M.A., Gómez Tovar, L. and Schwentesius Rinderman, R. (2003), "México como abastecedor de productos orgánicos”, Comercio Exterior, Vol. 53 No. 2, pp. 128-138.

Goodman, D. and Goodman, M.K. (2009), "Alternative food networks", International Encyclopedia of Human Geography, Elsevier, Amsterdam, pp. 208-220.

Goodman, D., DuPuis, E.M. and Goodman, M.K. (2012), Alternative Food Networks. Knowledge, Practice and Politics, Routledge, London.

Grunert, K.G., Perrea, T., Zhou, Y., Huang, G., Sørensen, B.T. and Krystallis, A. (2011), "Is food-related lifestyle (FRL) able to reveal food consumption patterns in non-western cultural environments? Its adaptation and application in urban china", Appetite, Vol. 56 No. 2, pp. 357-367.

Hair, J., Anderson, R., Tatham, R. and Black, W. (1999), Análisis Multivariante, Prentice Hall Iberia, Madrid.

Hjelmar, U. (2011), “Consumers' purchase of organic food products: a matter of convenience and reflexive practices", Appetite, Vol. 56 No. 2, pp. 336-344.

Junta de Andalucía (2016), "La superficie de producción ecológica en Andalucía supera el millón de hectáreas”, Consejería de Agricultura, Ganadería, Pesca y Desarrollo Sostenible, available at: www.juntadeandalucia.es/organismos/agriculturaganaderiapescaydesarrollosostenible/ actualidad/noticias/detalle/120364.html (accessed November 2017).

Keith, C.R., Lawrence, D.K., Padgett, T.C. and Renckly, T.R. (2002), Air University Sampling and Surveying Handbook, Air University, AFB Maxwell, AL, pp. 1-88.

Kriwy, P. and Mecking, R.A. (2012), "Health and environmental consciousness, costs of behaviour and the purchase of organic food", International Journal of Consumer Studies, Vol. 36 No. 1, pp. 30-37.

Krom, M.P. and Mol, A.P. (2010), "Food risks and consumer trust. Avian influenza and the knowing and non-knowing on UK shopping floors", Appetite, Vol. 55 No. 3, pp. 671-678.

Lang, T. (2010), "Crisis? What crisis? The normality of the current food crisis", Journal of Agrarian Change, Vol. 10 No. 1, pp. 87-97. 
Langen, N. (2012), "An empirical analysis based on the example of coffee”, Ethics in Consumer Choice, Springer Gabler, Bonn, pp. 169-329.

Lee, H.J. and Yun, Z.S. (2015), “Consumer's perceptions of organic food attributes and cognitive and affective attitudes as determinants of their purchase intentions toward organic food", Food Quality and Preference, Vol. 39, January, pp. 259-267.

Lim, W.M., Yong, J.L.S. and Suryadi, K. (2014), "Consumers' perceived value and willingness to purchase organic food”, Journal of Global Marketing, Vol. 27 No. 5, pp. 298-307.

López García, D. (2011), "Canales cortos de comercialización como elemento dinamizador de las agriculturas ecológicas urbana y periurbana”, I Congreso Estatal de Agricultura Ecológica Urbana y Periurbana, Cáceres.

Martín, M., Cabero, M. and De Paz, S. (2008), Tratamiento Estadístico de Datos con SPSS, Thomson-Paraninfo, Madrid.

Maye, D. and Kirwan, J. (2010), “Alternative food networks”, Sociology of Agriculture and Food, Vol. 20 No. 3, pp. 383-389.

Mohamad, S.S., Rusdi, S.D. and Hashim, N.H. (2014), "Organic food consumption among Urban consumers: preliminary results”, Procedia-Social and Behavioural Sciences, Vol. 130, May, pp. 509-514.

Monteiro-Viana, M., Dos Santos Silva, V.L. and Trindade, M.A. (2014), “Consumers' perception of beef burgers with different healthy attributes", LWT-Food Science and Technology, Vol. 59 No. 2, pp. 1227-1232.

Olsen, N.V. and Bánáti, D. (2014), "Ethics in food safety management", Food Safety Management, Chapter 46, Academic Press, Cambridge, MA, pp. 1115-1125.

Pedroza, H. and Discovsky, L. (2006), Sistema de Análisis Estadístico con SPSS, Instituto Nicaragüense de Tecnología Agropecuaria, Managua, pp. 118-144.

Pérez Izquierdo, O., Nazar Beutelspacher, A., Salvatierra Izaba, B., Pérez-Gil Romo, S.E., Rodríguez, L., Castillo Burguete, M.T. and Mariaca Méndez, R. (2012), "Frecuencia del consumo de alimentos industrializados modernos en la dieta habitual de comunidades mayas de Yucatán, México", Estudios Sociales, Vol. 20 No. 39, pp. 155-184.

Petrescu, D.C. and Petrescu-Mag, R.M. (2015), "Organic food perception: fad, or healthy and environmentally friendly? A case on Romanian consumers", Sustainability, Vol. 7 No. 9, pp. 12017-12031.

Pinstrup-Andersen, P. (2011), "The food system and its interaction with human health and nutrition", in Fan, S. and Pandya, R. (Eds), Reshaping Agriculture for Nutrition and Health, International Food Policy Research Institute, Washington, DC, pp. 21-29.

Rojas-Rivas, E., Espinoza-Ortega, A., Martínez-García, C.G., Moctezuma-Pérez, S. and Thomé-Ortiz, H. (2018), "Exploring the perception of Mexican urban consumers toward functional foods using the free word association technique", Journal of Sensory Studies, Vol. 33 No. 5, pp. 1-11.

Schwentesius Rinderman, R. (2010), "Producción orgánica y mercados locales en México", available at: http://vinculando.org/organicos/produccion_organica_y_mercados_locales_en_ mexico (accessed November 3, 2014).

Sevilla Guzmán, E., Soler, M., Gallar, D., Vara, I. and Calle, A. (2012), "Canales cortos de comercialización alimentaria en Andalucía”, Sevilla: Fundación Pública Andaluza Centro de Estudios Andaluces, Consejería de la Presidencia e Igualdad, Junta de Andalucía, Vol. 201 No. 2, p. 1.

Simoncini, R. (2015), "Introducing territorial and historical contexts and critical thresholds in the analysis of conservation of agro-biodiversity by alternative food networks, in Tuscany, Italy", Land Use Policy, Vol. 42, January, pp. 355-366.

Steptoe, A., Pollard, T.M. and Wardle, J. (1995), "Development of a measure of the motives underlying the selection of food: the food choice questionnaire", Appetite, Vol. 25 No. 3, pp. 267-284. 
Stolz, H., Stolze, M., Hamm, U., Janssen, M. and Ruto, E. (2011), "Consumer attitudes towards organic versus conventional food with specific quality attributes", NJAS-Wageningen Journal of Life Sciences, Vol. 58 No. 3, pp. 67-72.

Tavernier, J. (2011), "Food citizenship: is there a duty for responsible coonsumption?", Journal of Agricultural and Environmental Ethics, Vol. 25 No. 6, pp. 895-907.

Teng, C.C. and Wang, Y.M. (2015), "Decisional factors driving organic food consumption: generation of consumer purchase intentions”, British Food Journal, Vol. 117 No. 3, pp. 1066-1081.

Tregear, A. (2011), "Progressing knowledge in alternative and local food networks: critical reflections and a research agenda", Journal of Rural Studies, Vol. 27 No. 4, pp. 419-430.

Tsourgiannis, L., Loizou, E., Karasavvoglou, A., Tsourgiannis, C.A. and Florou, G. (2015), “Consumers' purchasing behaviour patterns regarding organic wine in a southern EU country", 7th International Conference on Information and Communication Technologies in Agriculture in Kavala, Food and Environment, pp. 520-539.

Van Loo, E.J., Caputo, V., Nayga, R. and Verbeke, W. (2014), “Consumers' valuation of sustainability labels on meat", Food Policy, Vol. 49 No. 1, pp. 137-150.

Veen, E., Derkzen, P.H.M. and Wiskerke, J.S. (2012), "Motivations, reflexivity and food provisioning in alternative food networks: case studies in two medium-sized towns in The Netherlands", International Journal of Sociology of Agriculture and Food, Vol. 19 No. 3, pp. 365-382.

Vega-Zamora, M., Parras-Rosas, M., Murgado-Armenteros, E.M. and Tores-Ruiz, F.J. (2013), "The influence of the term organic food purchasing behaviour", Procedia - Social and Behavioural Sciences, Vol. 81, June, pp. 660-671.

Wu, L., Yin, S., Xu, Y. and Zhu, D. (2014), "Effectiveness of china's organic food certification policy: consumer preferences for infant milk formula with different organic certification labels", Canadian Journal of Agricultural Economics, Vol. 62 No. 4, pp. 545-568.

Zampila, J.P., Ayala, D.A.O. and Shewentesius, R.R. (2015), Desafios y prioridades de la agricultura orgánica en México, mirando a la Unión Europea, Centro de estudios para el Desarrollo Rural Sustentable, MC Editores.

Zander, K. and Hamm, U. (2010), "Consumer preferences for additional ethical attributes of organic food", Food Quality and Preference, Vol. 21 No. 5, pp. 495-503.

Zanoli, R., Gambelli, D. and Vairo, D. (2012), "Scenarios of the organic food market in Europe", Food Policy, Vol. 37 No. 1, pp. 41-57.

\section{Further reading}

Ballesteros, C. (2010), "Bases morales, políticas y espirituales para un consumo transformador", Revista de Estudios Sociales y de Sociología Aplicada, Vol. 156 No. 1, pp. 65-96.

\section{About the authors}

Sttefanie Yenitza Escobar-López received Veterinary Medical Zootecnista from Autonomous University of the State of Mexico (UAEMex) and Master of Science in Agricultural and Natural Resources from the Autonomous University of the State of Mexico. She has published in Revista Mexicana de Ciencias Pecuarias, and the British Food Journal. Phd Student of the Autonomous University of the State of Mexico (UAEMex).

Angélica Espinoza-Ortega is Doctor in Health and Animal Production Sciences from the National University Autonomous of Mexico. She has published in journals as Agrociencia, Técnica Pecuaria, Veterinaria México, Estudios Sociales, Economía Sociedad y Territorio, Journal of Agricultural Science, Tropical Animal Health and Production, Experimental Agriculture, Journal of Food Safety and CyTAJournal of Food and British Food Journal. She is part of the National System of Researchers Level II, and the Mexican Veterinary Academy. Her book Los quesos Mexicanos genuinos won the Gourmand World Cookbook Award 2009 in Paris, France. Angélica Espinoza-Ortega is the corresponding author and can be contacted at: angelica.cihuatl@gmail.com

Carmen Lozano-Cabedo is Doctor from the University of Sevilla, and woks in the National University of Distance Education, Madrid. She has published in Revista Sociedades Rurales, Producción 
y Medio Ambiente: Agricultura Familiar en España, Sociología del Trabajo and Journal of Agriculture and Environmental Ethics. She is member of the Spanish Federation of Sociology.

Encarnación Aguilar-Criado is Doctor in Anthropology from the University of Sevilla, and Visiting Researcher in the Department of Anthropology at the University of California, Berkeley. She is leader of different research groups of Rural Development and Local Agro-food Systems in Europe and Latinamerica. She has published more than 100 papers (books and articles). She is the leader of the research group TECUDE (Territory, Culture and Development). Nowadays, she is Professor at the University of Sevilla and Director of the International University Menéndez Pelayo at Sevilla.

Santiago Amaya-Corchuelo is Doctor in Anthropology from the University of Sevilla. He is Visiting Professor at Universities in México, Colombia and Brasil. He is Specialist in areas such as cultural heritage, territorial development or quality GIs, and has published numerous works with this theme. Nowadays, he is Member of the research group TECUDE (Territory, Culture and Development) and Professor of Anthropology in the General Economy Department of the University of Cadiz.

For instructions on how to order reprints of this article, please visit our website: 